\title{
Chemical composition and natural durability of juvenile and mature heartwood of Robinia pseudoacacia $L$.
}

\author{
JOÃO V.F. LATORRACA ${ }^{1}$, OLIVER DÜNISCH ${ }^{2,3}$ and GERALD KOCH ${ }^{2}$ \\ ${ }^{1}$ Universidade Federal Rural do Rio de Janeiro, Rodovia BR 465, km 07, 23890-000 Seropédica, RJ, Brasil \\ ${ }^{2}$ Federal Research Centre for Forestry and Forest Products, Leuschnerstr. 91, 21031 Hamburg, Germany \\ ${ }^{3}$ Master school for Carpentry, Ebern, Gleusdorfer Str. 14, 96106 Ebern, Germany \\ Manuscript received on August 11, 2009; accepted for publication on July 12, 2010
}

\begin{abstract}
The aim of this study was to characterize the properties of juvenile and mature heartwood of Robinia pseudoacacia L. (black locust). The content, the composition, and subcellular localization of heartwood extractives were studied in 14 old-grown trees from forest sites in Germany and Hungary, as well as in 16 younger trees of four clone types. Heartwood extractives (methanol and acetone extraction) were analysed by HPLC-chromatography. UV microspectrophotometry was used to localize the extractives in the wood cell walls. The natural durability of juvenile and mature heartwood was analysed according to the European standard EN 350-1. Growth analyses, as well as the chemical analyses, showed that in Robinia the formation of juvenile wood is restricted to the first 10-15 years of cambial growth. In the heartwood high contents of phenolic compounds and flavonoids were present, which were in high concentrations in the cell walls of the axial parenchyma and of the vessels. In the juvenile heartwood, the content of these extractives is significantly lower than in the mature heartwood. In agree, the juvenile heartwood had a lower resistance to decay by Coniophora puteana (brown rot fungus) and Coriolus versicolor (white rot fungus) compared to the mature.
\end{abstract}

Key words: Juvenile Wood, Natural durability, Wood chemical.

\section{INTRODUCTION}

Wood is the most important renewable raw material worldwide. A considerable amount of $\mathrm{CO}_{2}$ is fixed in the xylem of trees. Therefore the use of wood in long, lasting applications, like indoor and outdoor constructions, contributes significantly to the reduction of the $\mathrm{CO}_{2}$-concentration in the atmosphere and impacts on the global climate. However, in many applications, the life cycle of wood is limited by its natural durability. Consequently, during the last years, the demand for timber with high natural durability increased significantly. Recently this tendency is favoured by the increased outdoor use of wood also due to optical reasons.

Correspondence to: João Vicente de Figueiredo Latorraca E-mail: latorraca@ufrrj.br
For decades, the timber market of high durable timber concentrated on tree species from the tropics. These tropical species have been heavily exploited in natural forests because of their highly desirable physical and chemical properties, and now demand exceeds supply in the international timber market. In Europe very few tree species produce timber with a very high natural durability (Grosser 2003). One of the few promising species is Robinia pseudoacacia L. (black locust), which is native in North America, but cultivated in Europe for more than 400 years (Stringer 1992, Molnar 1995). Many investigations elucidated the fast formation of heartwood in Robinia and its high natural durability (Hart 1968, Magel et. al. 1991, 1994).

However, several studies also proved a high variability of wood in the properties of Robinia wood (Chow 
et al. 1996, Adamopoulus et al. 2005). Some authors suppose that differences between juvenile and mature wood are responsible for the variety in wood quality of Robinia (Stringer and Olson 1987). Differences between wood formed during the juvenile and adult growth phases are described for many species, but most of the studies focus on the anatomical structure and the elasto-mechanical properties of the wood (Kopitovic et al. 1989, Zobel and van Buijtenen 1989, Zobel and Sprague 1998). However, recent studies also indicate significant differences of chemical properties between juvenile and mature heartwood. Haupt et al. (2003) found a lower concentration of wood extractives in the juvenile heartwood of Tectona grandis (Teak) compared to the mature heartwood, corresponding to a lower natural durability of the juvenile wood compared to the mature. In contrast, studies on the chemical composition and the natural durability of juvenile and mature heartwood in Robinia revealed differing results (Chow et al. 1996, Adamopoulus et al. 2005).

The aim of the present study was to investigate the content and distribution of extractives in juvenile and mature heartwood of the Robinia acacia and its significance for the natural durability of the wood.

\section{EXPERIMENTAL}

\section{WOOD SAMPLING}

Stem discs (height approx. $1.3 \mathrm{~m}$ ) from 14 old-grown Robinia pseudoacacia trees from forest sites in EasternGermany (Eberswalde) and Eastern Hungary (Nyiracsàd, South-Nyirség 61) were sampled in late September 2005 and in late September 2006, respectively (Table I). In addition, stem discs (height approx. $0.5 \mathrm{~m}$ ) of four 11-year-old Robinia peseudoacacia clones (clones 2402, 2405, 2461, 2498, four trees per clone) grown at the experimental site of the Institute for Forest Genetics and Forest Breeding, Federal Research Centre for Forestry and Forest Products in Waldsieversdorf (Eastern-Germany) were sampled in October 2005 (Table I). The discs were shock-frozen and stored in a freezer $\left(-18^{\circ} \mathrm{C}\right)$ until subsequent sample processing. Samples for increment analyses, chemical analysis, and Ultraviolet (UV) microspectrophotometry were taken from areas adjacent to each other on the discs.

\section{INCREMENT ANALYSIS}

The annual rings width was measured on sanded discs along four radii (north, south, east, west) with a digital ocular lens. The increment curves were visually crossdated between trees of the same site according to Fritts (1976). Cross-dating was successful for the oldgrown trees from "Eberswalde" and "South-Nyirség", while cross-dating failed for the 11-year-old clones from "Waldsieversdorf".

\section{Chemical Analysis}

The lignin contents of sawood (the closer sawood rings to cambium and heartwood were not used) and heartwood (the closer rings to sapwood were no used) was determined as "Klason"-lignin according to the TAPPIprocedure $2220 \mathrm{~m}-88$. The acid soluble fraction was quantified photometrically at a wavelength of $205 \mathrm{~nm}$.

For the determination of extractive content, wood samples were milled and sifted with $2 \mathrm{~mm}$. The extractives were isolated from wood methanol/water (4:1) extraction in according to Puls and Rademacher (1986) and acetone/water extraction (3:1) in according to Magel et al. (1994). For, quantification of the total extractives content, the extracts were concentrated in vacuo at $40^{\circ} \mathrm{C}$, purged with nitrogen and dried over phosphorus pentoxyde. The dry extracts were weighted and their content in the samples was expressed as percentage of dry mass of the original sample. Parallel extracts were separated by High Performance Liquid Chromatography (HPLC), and the contents of isolated Robinetin and Dihydrorobinetin were determined quantitatively according to the procedure described by Mayer and Koch (2007).

\section{UltraViolet (UV) MicRosPeCtROPHOTOMETRY}

Small wood blocks from heartwood of clones and native trees $(1 \times 1 \times 5 \mathrm{~mm})$ were dehydrated in a graded series of acetone and then impregnated with Spurr's resin (Spurr 1969). Semi-thin (thickness $1 \mu \mathrm{m}$ ) cross sections of the samples were prepared using a diamond knife. These sections were transferred to quartz microscope slides, immersed in a drop of non-UV absorbing glycerine, and covered with a quartz cover slip. The sections were observed using a Zeiss UMSP 80 microspectrophotometer (Koch and Kleist 2001). The UV absorb- 
TABLE I

Number and age of the experimental trees from the sites "Eberswalde", "Waldsieversdorf" (both Germany), and "South-Nyirség", Hungary.

\begin{tabular}{c|c|c|c}
\hline Reproduction & Site & $\begin{array}{c}\text { No. of } \\
\text { trees }\end{array}$ & $\begin{array}{c}\text { Tree age } \\
\text { (years) }\end{array}$ \\
\hline Seeds & Eberswalde, Germany & 10 & $59-85$ \\
\hline Seeds & South-Nyirség, Hungary & 4 & 41 \\
\hline $\begin{array}{c}\text { Clones } \\
(2402,2405,2461,2498)\end{array}$ & Waldsieversdorf, Germany & 16 & 11 \\
\hline
\end{tabular}

ance of the samples was determining by point measurements (ultrafluar objective 32: 1, 1.46 oil, spot size $1 \mu \mathrm{m}^{2}$ ) between 240 and $400 \mathrm{~nm}$ wavelength using the program LAMWIN ${ }^{\circledR}$ (Zeiss). In addition, UV absorbance profiles at constant wavelengths were generated in the scanning mode of the microspectrophotometer using the scan program APAMOS ${ }^{\circledR}$ (Zeiss). The scan program creates absorbance profiles at constant wavelengths with a spatial resolution of $0.25 \mu \mathrm{m}^{2}$ and a photometrical resolution of 4096 grey scales, which are converted into 14 basic colours visualising the intensity of absorbance (Irbe et al. 2006).

\section{In vitro DECAY TEST}

The natural durability of juvenile and the mature wood, was tested according to the European standard EN 350-1. For the decay test, the basidiomycete fungi Coniophora puteana and Coriolus versicolor were chosen. The fungi virulence was tested using samples from Pinus sylvestris (sapwood) and Fagus sylvatica wood. In total, 64 samples of juvenile heartwood and 50 samples of mature heartwood were included in this analyses. The durability class of juvenile wood and mature wood was calculated according to the European standard EN 350-2.

\section{RESULTS AND DISCUSSION}

\section{TreE Ring Width OF THE EXPERIMENTAL TREES}

The annual growth increment of all trees decreased significantly from pith to cambium (Fig. 1). In particular, during the first 10 to 20 years of growth, the annual increment exceeded the growth rate of older trees. The analysis of the increment indicates a juvenile phase of growth of the Robinia trees of approximately 10-20 trees as a maximum, while a distinct phase of adult growth was found in trees older than 20 years. Consequently, for the analyses of the chemical composition and the natural durability of the wood, samples of the tree rings 1 to 10 were selected for the characterisation of juvenile wood, while samples of tree rings formed by trees older than 20 years were selected for the characterisation of mature wood.

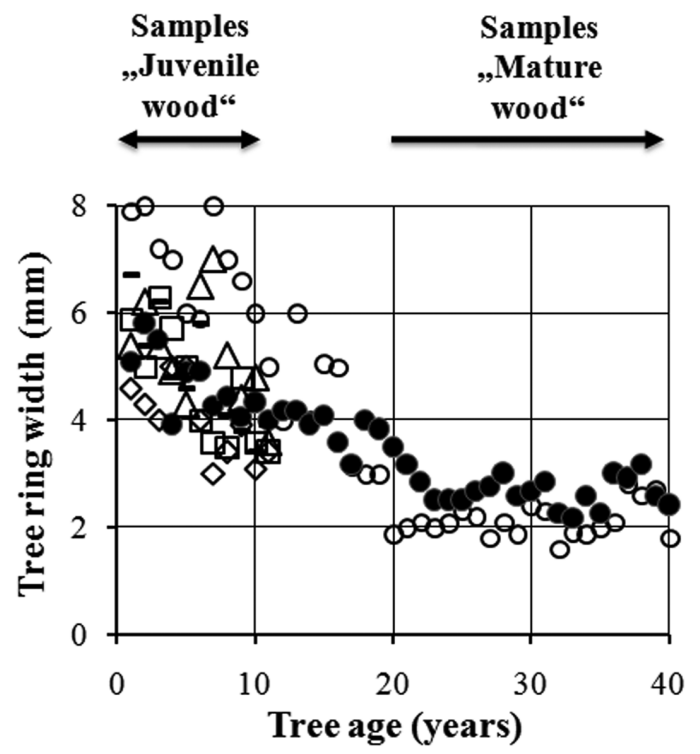

Fig. 1 - Tree ring width $(\mathrm{mm})$ of the experimental trees from the sites "Eberswalde" (•), "South-Nyirség" (०), and "Waldsieversdorf" ( $\Delta$ clone $2402, \triangle$ clone2405, $\square$ clone 2461, -clone 2498). Samples from the tree rings 1 to 10 were selected for the analyses of the wood properties of the juvenile wood. Samples from the tree rings 20 to 40 were selected for the analyses of the wood properties of the mature wood.

The dating of the phase of juvenile and mature wood formation based on increment measurements corresponds to results obtained for anatomical characteristics and elastomechanical properties of Robinia wood (Dünisch et al. 2007). This indicates that growth and 
wood characteristics in Robinia are tightly linked to each other with regard to the formation of juvenile and mature wood.

\section{Lignin AND EXTRACTIVE CONTENT OF JUVEniLE AND MATURE WOOD}

Although the lignin and extractive content in the juvenile and mature sapwood/heartwood of the trees varied in dependence on the genotype and the site conditions, significant differences of the chemical composition between sapwood and heartwood and juvenile and mature wood, were found (Table II). For the interpretation of the results, it must be considered that the juvenile and mature sapwood and heartwood of the trees had to be collected at different stem heights. Beside, the cambium age, the sampling position might influence the chemical composition of the wood, but the studies of Adamopoulus et al. (2005) indicate only a small influence of exogenous input along the stem axis on the chemical composition of the wood. Therefore, in this study, the sampling position was not considered analysing the lignin and extractive content.

The "Klason"-lignin content in the samples varied between $19.8 \%$ and $25.8 \%$. In the heartwood samples, the lignin content was higher than in the sapwood. The higher content of "Klason"-lignin in the heartwood might be caused by the higher content of lignin-like phenolic compounds in the heartwood, which were not separated from the pure lignin due to methodological limitations of the analytical procedure (Fengel and Wegener 1984). However, both, in the sapwood and in heartwood, the lignin content in the mature wood was higher than in the juvenile. In that case, methodological limitations are not very likely to be the reason for the result. The ultrastructure of cell walls formed during the juvenile phase of growth differs significantly from the ultrastructure of cell walls formed by an older cambium (Abe et al. 1995, Funada et al. 1997, Sahlberg et al. 1997). Several authors (cited in Adamopoulus et al. 2005) consider that in particular the fibrillar orientation in the $\mathrm{S}_{2}$-layer of the juvenile cells (higher micro fibril angle) is related to the lower lignin content of the juvenile wood.

In agree with studies of Magel et al. (1991, 1994), the analyses of heartwood extractives in individual tree rings from the cambium to the pith showed that the formation of heartwood starts after three to four years and lasts two years. In the sapwood, detectable wood extractives were exclusively found in the methanol extracts, while heartwood extractives were found in the methanol and in the acetone fraction. In the sapwood of Robinia, non-structural carbohydrates and lipids (Magel et al. 1991, Hillinger et al. 1996), which are soluble in methanol, are present. The living tree uses these substances particularly for the formation of the heartwood.

The content of heartwood extractives was higher in the mature heartwood than in the heartwood formed during the juvenile phase. The separation of the extractives by HPLC-chromatography showed that, in the heartwood of Robinia high contents of flavonoids are present, whereby Robinetin and Dihydrorobinetin were the dominant components (Figs. 2-3). The comparison of HPLC-chromatograms of heartwood extracts from younger and older trees showed that the chemical composition of extractives in the heartwood formed by younger trees (juvenile heartwood) is very similar to the chemical composition of heartwood extractives formed by older trees (mature heartwood). This indicates that, in juvenile and mature wood of Robinia the chemical pathway (Magel et al. 2001, Yang et al. 2004) of heartwood formation is identical. However, the reduced content of heartwood extractives in the juvenile wood compared to the mature wood is important for the use of the inner heartwood of Robinia stems.

\section{SUBCELLULAR LOCALIZATION OF LIGNIN AND WOOD EXTRACTIVES}

The UV absorbance of lignin depends on the ratio of p-hydroxyphenyl-, guaiacyl-, and syringyl units. The lignin in the xylem of the Robinia samples had a maximum UV absorption at a wavelength of $278 \mathrm{~nm}$. Flavonoids also have a strong UV absorbance, but the highest absorption depend, on the chemical binding to the cell wall. For the detection of flavonoids in the cell walls of the heartwood, the UV absorbance behaviour between 240 and $400 \mathrm{~nm}$ wavelength is of special interest (Dietz 2002, Koch et al. 2006).

In all cell walls of sapwood and heartwood tissue maximum light absorbance was found at a wavelength of $278 \mathrm{~nm}$ indicating that light absorbance was domin- 


\section{Acetone}

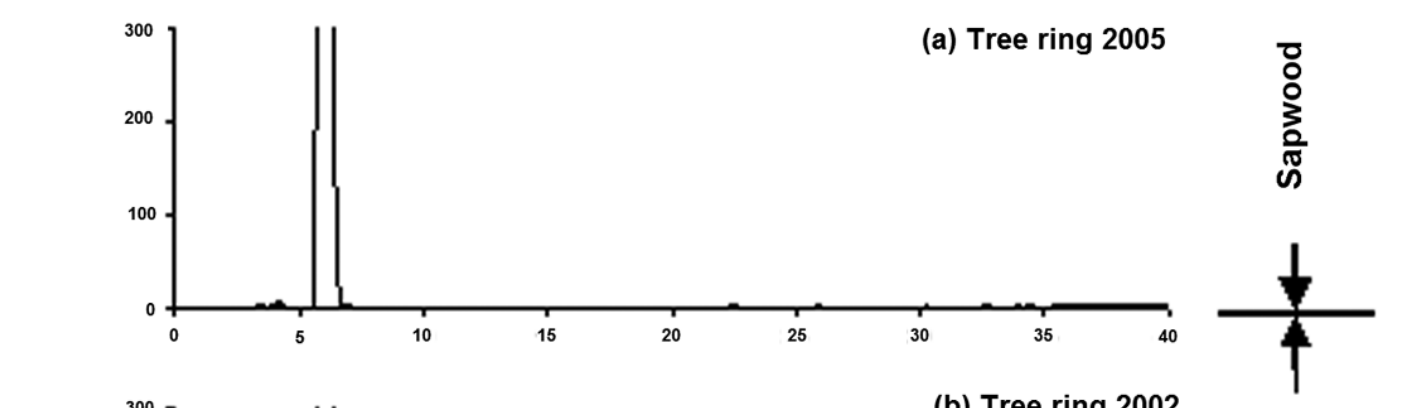

(b) Tree ring 2002
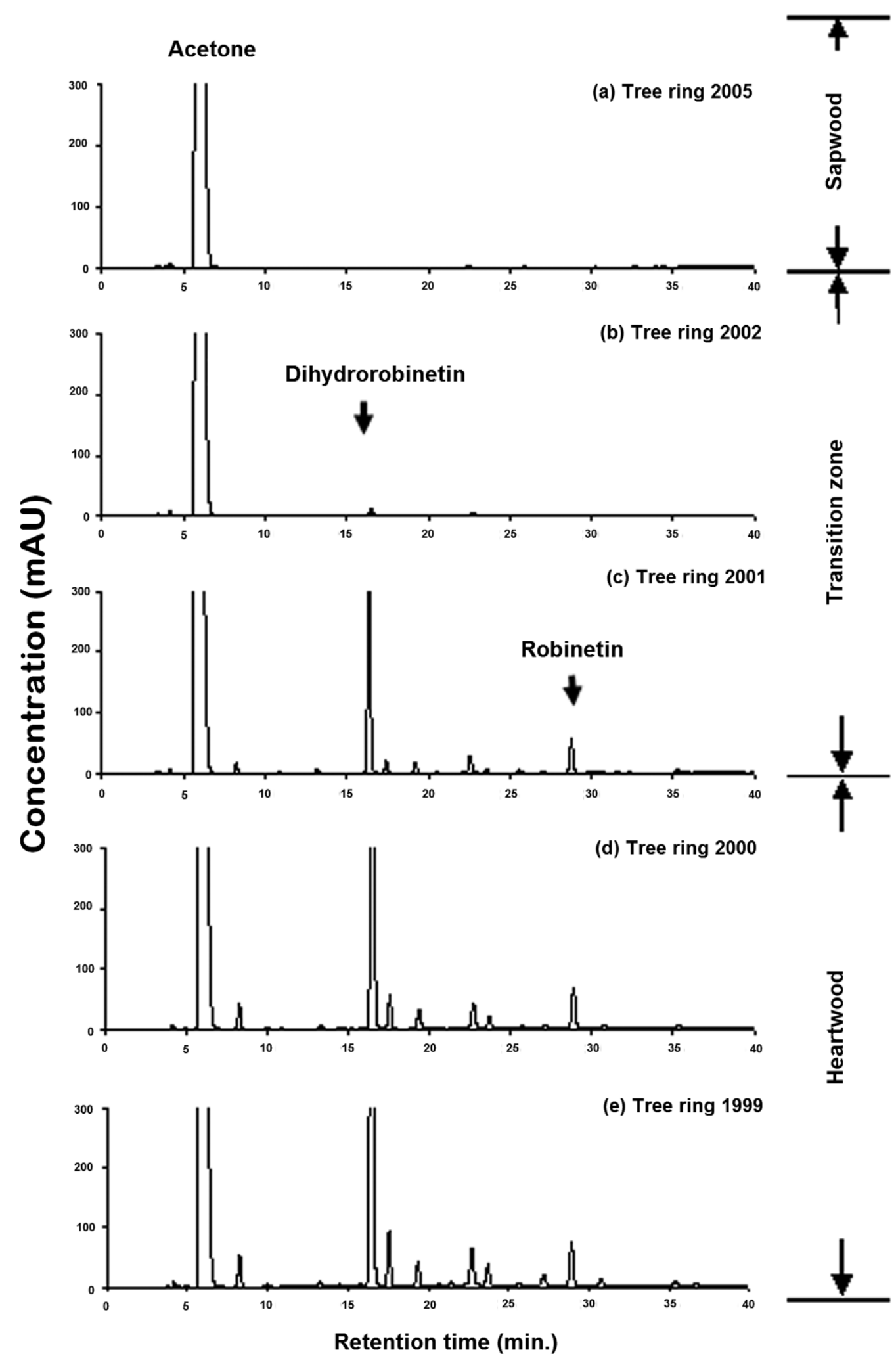

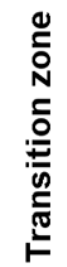

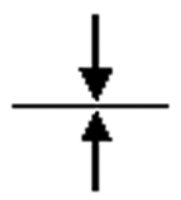

8
$\vdots$
$\vdots$
$\frac{1}{\pi}$
$\frac{\pi}{1}$

Fig. 2 - Extractive content (mAU, acetone extract) in the sapwood, in the sapwood-heartwood transition zone, and in the heartwood of a 11years-old Robinia tree (clone 2498, site "Waldsieversdorf"). HPLC-chromatography, $280 \mathrm{~nm}$ wavelength. The retention time of the flavonoids Robinetin and Dihydrorobinetin is marked by arrows. 

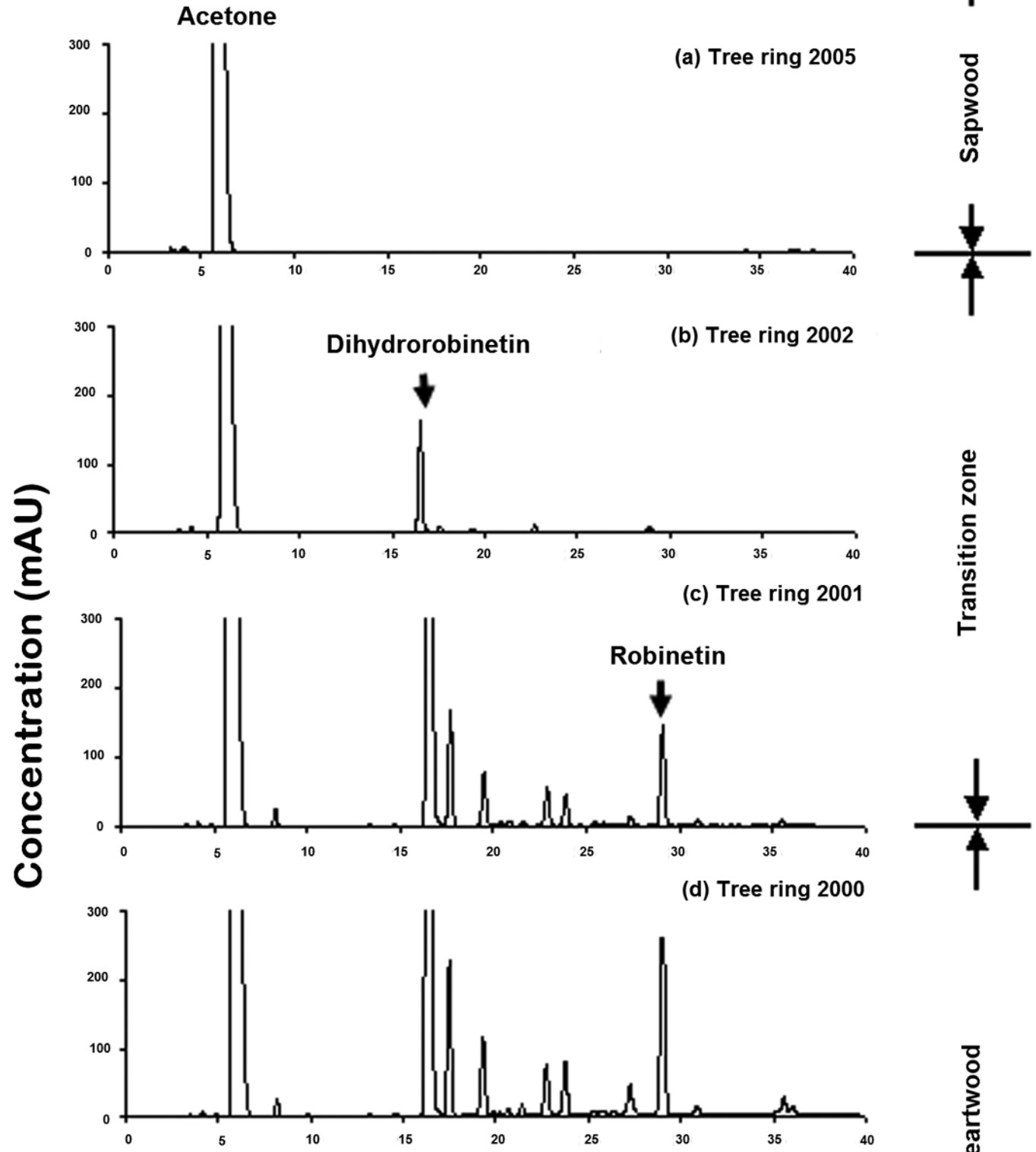

(e) Tree ring 1999
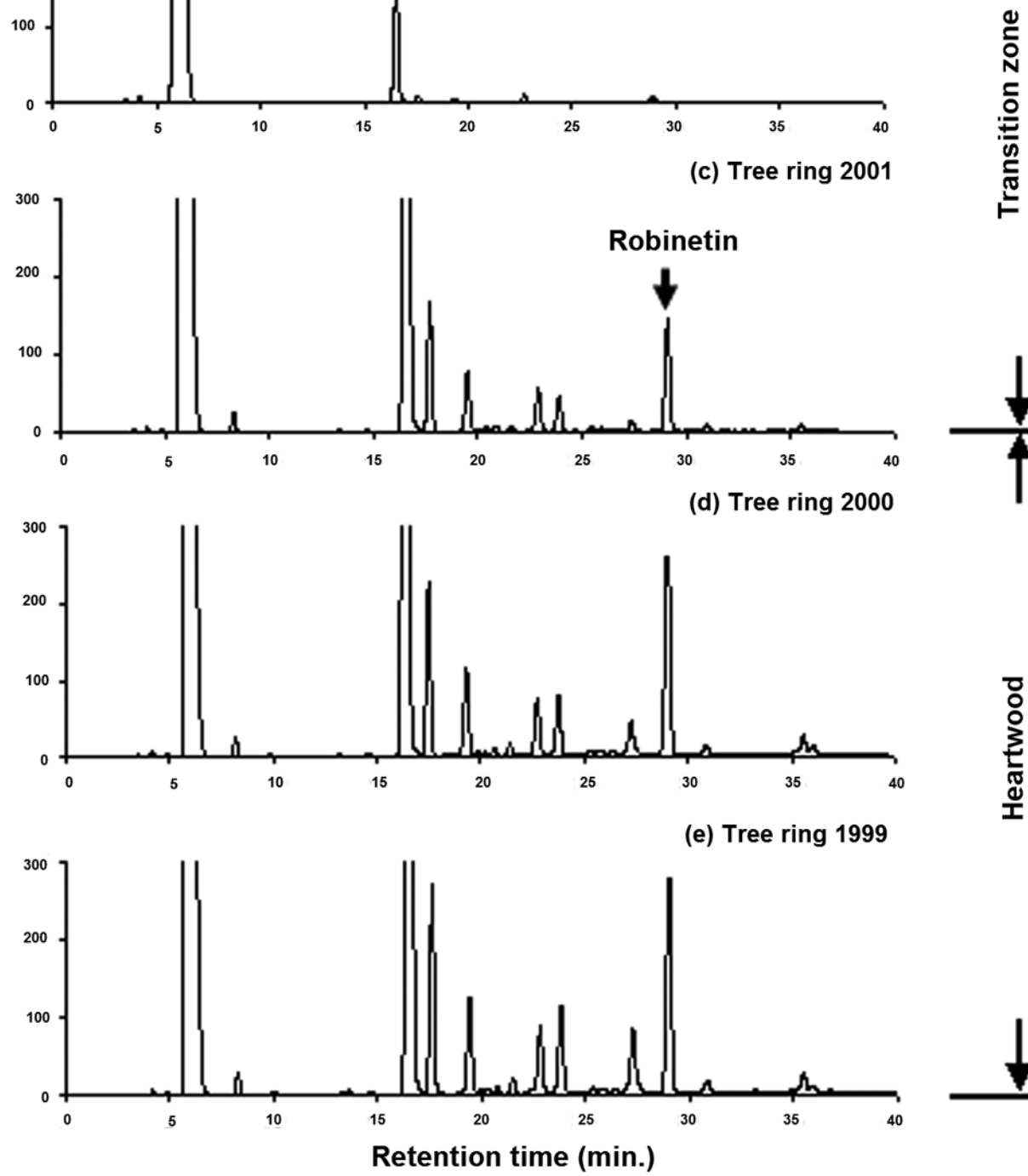

응
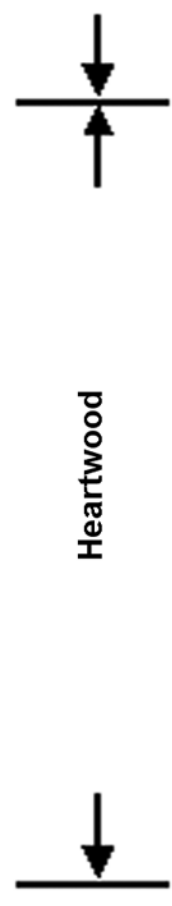

Fig. 3 - Extractive content (mAU, acetone extract) in the sapwood, in the sapwood-heartwood transition zone, and in the heartwood of a 59years-old Robinia tree (site "Eberswalde"). HPLC-chromatography, $280 \mathrm{~nm}$ wavelength. The retention time of the flavonoids Robinetin and Dihydrorobinetin is marked by arrows. 
TABLE II

Lignin and extractive content (\%; mean values \pm standard deviation.) of juvenile and mature sapwood and heartwood of Robinia pseudoacacia $L$. Total no. of samples $=$ No. of trees $\times$ No. of samples per tree. N.d. $=$ not detectable.

\begin{tabular}{|c|c|c|c|c|c|c|}
\hline & Sampling position & $\begin{array}{c}\text { Trees/sites } \\
\text { samples }\end{array}$ & $\begin{array}{c}\text { No. of } \\
(\%)\end{array}$ & $\begin{array}{c}\text { Lignin } \\
\mathrm{MeOH} / \mathrm{H}_{2} \mathrm{O}(\%)\end{array}$ & $\begin{array}{c}\text { Extractives } \\
\text { acetone }(\%)\end{array}$ & Extractives \\
\hline $\mathrm{S}$ & $\begin{array}{l}\text { Juvenile wood } \\
\text { Mature wood }\end{array}$ & Eberswalde & $20(10 \times 2)$ & $\begin{array}{l}21.8 \pm 2.1 \\
23.2 \pm 2.4\end{array}$ & $\begin{array}{l}3.9 \pm 0.4 \\
3.8 \pm 0.9\end{array}$ & n.d. \\
\hline $\mathrm{p}$ & $\begin{array}{c}\text { Juvenile wood } \\
\text { Mature wood }\end{array}$ & South-Nyirség & $8(4 \times 2)$ & $\begin{array}{l}20.7 \pm 3.4 \\
20.9 \pm 2.9\end{array}$ & $\begin{array}{l}3.2 \pm 0.8 \\
3.1 \pm 1.1\end{array}$ & n.d. \\
\hline $\begin{array}{l}\mathrm{W} \\
\mathrm{o} \\
\mathrm{o} \\
\mathrm{d}\end{array}$ & Juvenile wood & $\begin{array}{l}\text { Clone 2402, Waldsieversdorf } \\
\text { Clone 2405, Waldsieversdorf } \\
\text { Clone 2461, Waldsieversdorf } \\
\text { Clone 2498, Waldsieversdorf }\end{array}$ & $\begin{array}{l}8(4 \times 2) \\
8(4 \times 2) \\
8(4 \times 2) \\
8(4 \times 2)\end{array}$ & $\begin{array}{l}19.8 \pm 3.1 \\
20.2 \pm 2.7 \\
20.1 \pm 3.4 \\
22.4 \pm 3.0 \\
\end{array}$ & $\begin{array}{l}3.8 \pm 0.7 \\
4.2 \pm 1.2 \\
3.6 \pm 0.7 \\
3.5 \pm 0.7\end{array}$ & $\begin{array}{l}\text { n.d. } \\
\text { n.d. } \\
\text { n.d. } \\
\text { n.d. }\end{array}$ \\
\hline $\begin{array}{l}\mathrm{H} \\
\mathrm{e}\end{array}$ & $\begin{array}{l}\text { Juvenile wood } \\
\text { Mature wood }\end{array}$ & Eberswalde & $20(10 \times 2)$ & $\begin{array}{l}23.1 \pm 1.9 \\
25.8 \pm 3.5\end{array}$ & $\begin{array}{l}0.9 \pm 0.2 \\
1.3 \pm 0.4\end{array}$ & $\begin{array}{l}5.7 \pm 1.3 \\
8.5 \pm 0.8\end{array}$ \\
\hline $\begin{array}{l}\mathrm{a} \\
\mathrm{r}\end{array}$ & $\begin{array}{l}\text { Juvenile wood } \\
\text { Mature wood }\end{array}$ & South-Nyirség & $8(4 \times 2)$ & $\begin{array}{l}22.4 \pm 1.8 \\
23.7 \pm 2.9\end{array}$ & $\begin{array}{l}1.6 \pm 0.4 \\
1.5 \pm 0.5\end{array}$ & $\begin{array}{l}6.1 \pm 0.9 \\
8.8 \pm 1.5\end{array}$ \\
\hline $\begin{array}{l}\text { w } \\
\text { o } \\
\text { o } \\
\text { d }\end{array}$ & Juvenile wood & $\begin{array}{l}\text { Clone 2402, Waldsieversdorf } \\
\text { Clone 2405, Waldsieversdorf } \\
\text { Clone 2461, Waldsieversdorf } \\
\text { Clone 2498, Waldsieversdorf }\end{array}$ & $\begin{array}{l}8(4 \times 2) \\
8(4 \times 2) \\
8(4 \times 2) \\
8(4 \times 2)\end{array}$ & $\begin{array}{l}22.4 \pm 2.8 \\
20.9 \pm 1.9 \\
21.6 \pm 2.4 \\
23.0 \pm 2.7\end{array}$ & $\begin{array}{l}1.7 \pm 0.3 \\
2.4 \pm 0.3 \\
1.9 \pm 0.5 \\
2.4 \pm 0.5\end{array}$ & $\begin{array}{l}4.9 \pm 0.7 \\
4.8 \pm 0.5 \\
5.7 \pm 1.3 \\
3.9 \pm 0.7\end{array}$ \\
\hline
\end{tabular}

ated by lignin (Fig. 4a-c). However, in the total range of wavelength (240-400 nm), light absorbance of vessel and axial parenchyma was higher in the heartwood than in the sapwood, while higher light absorbance of fibre cell walls was restricted to the range of wavelength between 240 to $290 \mathrm{~nm}$. This indicates that UV absorbing heartwood extractives are located in a higher concentration in the cell walls of vessels and axial parenchyma than in cell walls of fibres.

The exact localization of the important flavonoids Robinetin and Dihydrorobinetin was not possible by subcellular UV-microspectrophotometry, although pure substances have distinct maxima of UV-absorbance. Koch et al. (2006) found pure Robinetin in heartwood vessels of Intsia spp. Differing from observation, the absorbance spectra indicate that, in the heartwood of Robinia, these flavonoids are not present in their pure form (Fig. 4a-c). The UV-absorbance of Robinetin and Dihydrorobinetin in situ depends on the ligands and the chemical binding to the cell wall (Dietz 2002). The absorbance spectra indicate a wide range of ligands and binding types of Robinetin and Dihydrorobinetin in the heartwood of Robinia.
The high resolution mapping of the UV absorbance of juvenile and mature heartwood confirmed the results obtained by bulk analyses of heartwood extracts (Table II). Cell walls of vessels and axial parenchyma of juvenile heartwood had a lower UV absorbance (240$400 \mathrm{~nm}$ ) compared to cell walls of vessels and axial parenchyma in the mature heartwood. This indicates a higher content of flavonoids in the wall of these cells. Fibre cell walls of the juvenile heartwood had a lower maximum of absorbance at a wavelength of $278 \mathrm{~nm}$ compared to fibre cell walls in the mature heartwood. This gives evidence for a lower lignin content of fibre cell walls in the juvenile wood compared to the mature wood (Fergus and Goring 1970a, b), explaining the slightly reduced "Klason"-lignin content of the juvenile wood compared to the mature wood (Table II).

\section{Natural Durability of JuVEnile And MATURE HEARTWOOD}

The fungus Coriolus versicolor (white rot fungi) caused a higher mass loss of the Robinia heartwood than the fungi Coniophora putenana (brown rot fungi). After 16 weeks of exposure, the mass loss of juvenile heartwood 

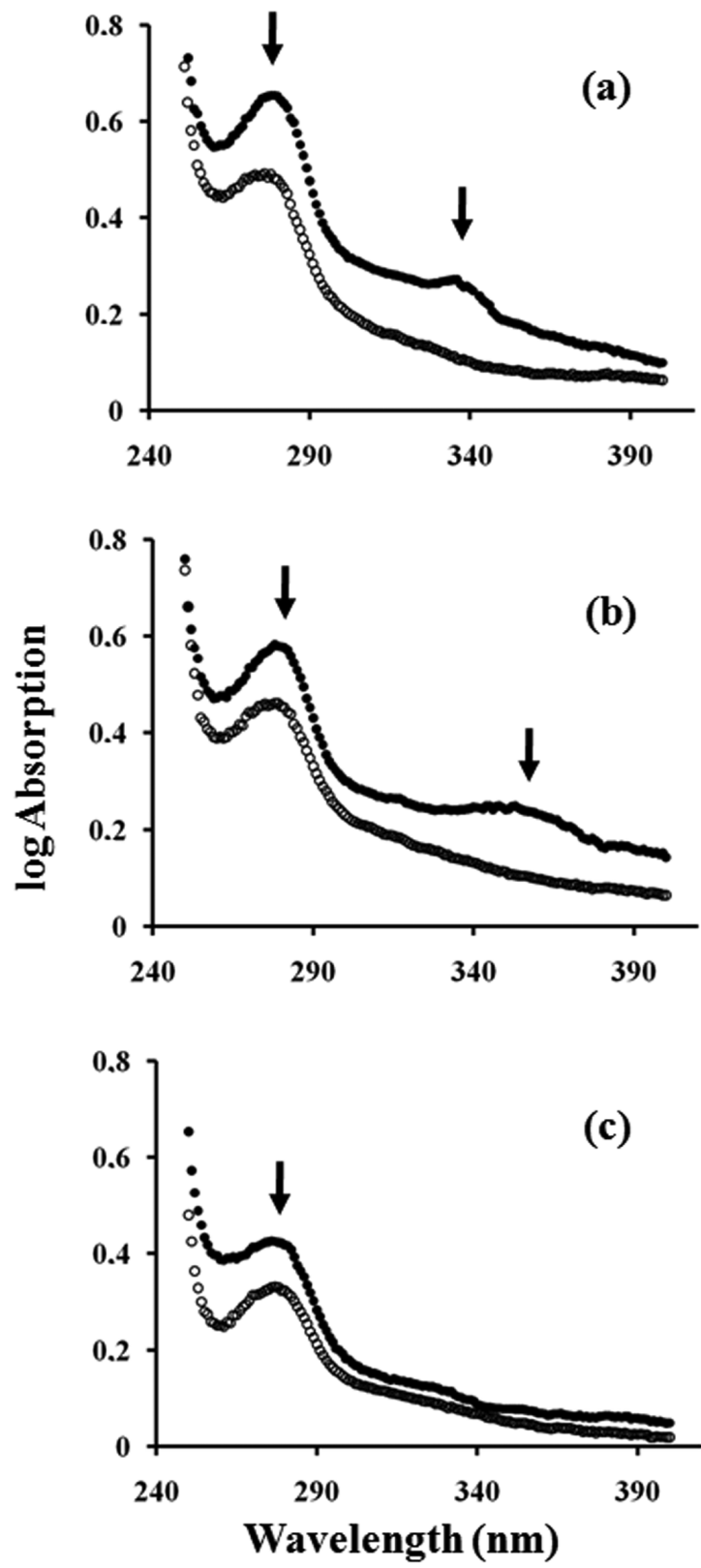

Fig. 4 - Representative UV absorption spectra (wavelength 250-400 $\mathrm{nm}$ ) of the cell walls of (a) a vessel, (b) an axial parechnyma cell, and (c) a fibre in the sapwood (०) and in the heartwood (•) of an old-grown Robinia tree (experimental site "Eberswalde"). Absorption maxima in the heartwood is marked by arrows.

was $10.1 \%$ (Coniophora puteana) and 17.0\% (Coriolus versicolor), while the mass loss of mature heartwood was only $0.7 \%$ (Coniophora puteana) and $1.7 \%$ (Coriolus versicolor, Table III). This shows that the natural durability of the juvenile heartwood is lower than the natural durability of the mature heartwood. According to the European standard EN 350-2, the juvenile heartwood samples are classed in durability class, 2-4 (resistant to little resistant), while the mature heartwood samples are classed in durability class 1 (highly resistant).

\section{CONCLUSION}

The investigations showed that the juvenile heartwood of Robinia pseudoacacia L. has a lower natural durability than the mature heartwood. The (topo-) chemical analyses indicate that the lower content of phenolic compounds and flavonoids in the juvenile heartwood is the main reason for its lower durability. The results also showed that the juvenile phase of growth of Robinia lasts approximately 10 years.

The heartwood of Robinia is highly demanded by users, especially for long, lasting outdoor applications. In order to ensure the wood quality of this promising tree species, the reduced durability of the juvenile heartwood should be considered in forestry (felling cycle) as well as during wood processing (grading).

\section{ACKNOWLEDGMENTS}

We thank the Deutsche Gesellschaft für Holzforschung, Munich (DGfH/AiF 14276 BG/1 N), the German Academic Exchange Service (DAAD), and Coordenação de Aperfeiçoamento de Pessoal de Nível Superior (CAPES) for financial support. We are indebted to A. Knöpfle and J. Puls for chemical analyses. We thank M. Lenz for the durability tests. The provision of experimental trees by K. Dreiner, V. Schneck, and E. Mayer is especially appreciated.

\section{RESUMO}

O objetivo deste estudo foi caracterizar as propriedades da região de cerne dos lenhos juvenis e adultos de Robinia pseudoacacia L. O conteúdo, a composição, bem como a localização subcelular dos extrativos foram estudados em 14 árvores de florestas de produção na Alemanha e na Hungria, assim como em 16 árvores de quatro tipos clone. Os extrativos (metanol e acetona extração) foram analisados por cromatografia-HPLC. O microespectrofotômetro de ultra violeta foi utilizado para localizar os extrativos nas paredes celulares da madeira. A durabilidade natural do lenho juvenil e adulto foi analisada de acordo com a norma europeia EN 350-1. Aná- 
TABLE III

Mass loss (\%; minimum-mean-maximum) of the juvenile and mature heartwood of Robinia pseudoacacia after 16 weeks of exposure to Coniophora puteana and Coriolus versicolor.

\begin{tabular}{|c|c|c|}
\hline $\begin{array}{c}\text { Sample } \\
\text { (No. of samples) }\end{array}$ & $\begin{array}{c}\text { Coniophora puteana } \\
\text { Mass loss }(\%)\end{array}$ & $\begin{array}{l}\text { Coriolus versicolor } \\
\text { Mass loss }(\%)\end{array}$ \\
\hline Virulence $(n=18)$ & $\begin{array}{c}\text { 56.6-60.6-64.3 } \\
\text { (Pinus sylvestris sapwood) }\end{array}$ & $\begin{array}{c}21.7-25.3-35.3 \\
(\text { Fagus sylvatica })\end{array}$ \\
\hline Juvenile wood $(n=64)$ & $\begin{array}{c}2.9-10.1-32.9 \\
\text { (Durabiliy class EN 350-2: 2) }\end{array}$ & $\begin{array}{c}\text { 4.8-17.0-33.0 } \\
\text { (Durabiliy class EN 350-2: 4) }\end{array}$ \\
\hline Mature wood $(n=50)$ & $\begin{array}{c}0.1-\underline{0.7-2.5} \\
\text { (Durabiliy class EN 350-2: 1) }\end{array}$ & $\begin{array}{c}0.5-1.7-4.8 \\
\text { (Durabiliy class EN 350-2: 1) }\end{array}$ \\
\hline
\end{tabular}

lises do incremento, bem como as análises químicas mostraram que, em Robinia a formação de lenho juvenil é limitada aos primeiros 10/15 anos de crescimento cambial. No cerne, elevados teores de compostos fenólicos e flavonóides foram encontrados e localizados em concentrações elevadas nas paredes celulares do parênquima axial e dos vasos. No cerno do lenho juvenil o conteúdo destes extrativos é significativamente menor do que no cerne do lenho adulto. O cerne do lenho juvenil apresentou menor resistência à degradação por Coniophora puteana (fungo de podridão parda) e Coriolus versicolor (fungo de podridão branca) em comparação com a madeira de lenho adulto.

Palavras-chave: lenho juvenil, durabilidade natural, química da madeira.

\section{REFERENCES}

Abe H, Funada R, Imaizumi H, Ohtani J and FukaZAWA K. 1995. Dynamic changes in the arrangement of cortical microtubules in conifer tracheids during differentiation. Planta 197: 418-421.

Adamopoulus S, Voulgaridis E and Passialis C. 2005. Variation of certain chemical properties within the stemwood of black locust (Robinia pseudoacacia L.) Holz als Roh- und Werkstoff 63: 327-333.

Chow P, Rolfe GL And Shupe TF. 1996. Some chemical constituents of ten-year-oldamerican sycamore and black locust in Illinois. Wood Fibre Sci 28: 186-193.

DiETZ B. 2002. Untersuchungen zu den Inhaltsstoffen von Echinacea atrorubens sowie zur Wirkung und Bioverfügbarkeit von Alkamiden. Diss Heinrich-Heine Universität, Düsseldorf.

DIN EN 350-1. 1994. Dauerhaftigkeit von Holz und Holzprodukten - Natürliche Dauerhaftigkeit von Vollholz -
Teil 1: Grundsätze für die Prüfung und Klassifikation der natürlichen Dauerhaftigkeit von Holz; Deutsche Fassung EN 350-1: 1994, Beuth Verlag GmbH, 12 p.

DIN EN 350-2. 1994. Dauerhaftigkeit von Holz und Holzprodukten - Natürliche Dauerhaftigkeit von Vollholz Teil 2: Leitfaden für die natürliche Dauerhaftigkeit und Tränkbarkeit von ausgewählten Holzarten von besonderer Bedeutung in Europa; Deutsche Fassung EN 350-2:1994, Beuth Verlag GmbH, 28 p.

DÜNISCH O, Koch G AND DREINER K. 2007. Verunsicherung über die Eigenschaften von Robinienholz. Holzzentralblatt 39: 1061-1062.

Fengel D And Wegener G. 1984. Wood chemistry. Walter de Gruyter, New York, 613 p.

FErgus BJ AND Goring DAI. 1970a. The location of guiacyl- and syringyl lignins in birch xylem tissue. Holzforschung 24: 113-117.

FERGUS BJ AND Goring DAI. 1970b. The distribution of lignin in birch wood as determined by ultraviolet microscopy. Holzforschung 24: 118-124.

FRITTS HC. 1976. Tree rings and climate. London, New York and San Francisco: Academic Press, 567 p.

Funada R, ABe H, Furusuwa O, Imaizumi H, FukaZAWA K AND OHTANI J. 1997. The orientation and localization of cortical microtubules in differentiating conifer tracheids during cell expansion. Plan Cell Physiol 38: $210-212$.

Grosser D. 2003. Die Hölzer Mitteleuropas. Verlag N Kessel, 87 p.

HART JH. 1968. Morphological and chemical differences between sapwood, discoloured wood, and heartwood in black locust and osage orange. Forest Sci 14: 334-338.

Haupt M, Leithoff H, Meier D, Richter HG AND FAIX O. 2003. Heartwood extractives and natural dura- 
bility of plantation-grown teakwood (Tectona grandis L.) - a case study. Holz als Roh- und Werkstoff 61: 473-474.

Hillinger C, Höll W AND Ziegler H. 1996. Lipids and lipolytic enzymes in the trunkwood of Robinia pseudoacacia $\mathrm{L}$. during heartwood formation. Trees 10 : 366-381.

Irbe I, Noldt G, Koch G, Andersone I And AnderSONS B. 2006. Application of scanning UV microspectrophotometry for the topochemical detection of lignin within individual cell walls of brown-rotted Scots pine (Pinus sylvestris) sapwood. Holzforschung 60: 601-607.

Koch G AND KLEIST G. 2001. Application of scanning UV microspectrophotometry to localise lignins and phenolic extractives in plant cell walls. Holzforschung 55: 563567.

Koch G, Richter HG AND Schmitt U. 2006. Topochemical investigation on phenolic deposits in the vessels of afzelia (Afzelia spp.) and merbau (Intsia spp) heartwood. Holzforschung 60: 583-588.

Kopitovic S, Klasnja B And Guzina V. 1989. Importance of structural, physical, and chemical properties of Robinia wood (Robinia pseudoacacia L.) for its mechanical characteristics. Drevarsky Vyskum 122: 13-30.

Magel E, Drouet A, Cloudot A And Ziegler H. 1991. Formation of heartwood substances in the stemwood of Robinia pseudoacacia L. I. Distribution of phenylalanine ammonium-lyase and chalcone synthase across the trunk. Trees 5: 203-207.

Magel E, Hillinger C, Wagner T And Höll W. 2001. Oxidative pentose phosphate pathway and pyridine nucleotides in relation to heartwood formation in Robinia pseudoacacia L. Phytochemistry 57: 1061-1068.

Magel E, JAY-Allemand C And ZIEgler H. 1994. Formation of heartwood substances in the stemwood of Robinia pseudoacacia L. II. Distribution of nonstructural carbohydrates and wood extractives across the trunk. Trees 8: 165-171.
MAYER I AND Koch G. 2007. Farbabweichungen bei Black Cherry nehmen zu. Holzzneralblatt 7: 200-202.

Molnar S. 1995. Wood properties and utilisation in Hungary. Drevarsky Vyskum 1: 27-33.

Puls J AND Rademacher P. 1986. Chemische Untersucungen an Fichte aus Waldschadensgebieten. Holz als Rohund Werkstoff 44: 307-312.

Sahlberg U, Salmén L and Oscarsson A. 1997. The fibrillar orientation in the $\mathrm{S}_{2}$-layer of wood fibres as determined by $\mathrm{x}$-ray diffraction analysis. Wood Sci Technol 31: 77-86.

SPURR AR. 1969. A low-viscosity epoxy resin embedding medium for electron microscopy. L. Ultrastructure Res 26: $31-43$.

STRINGER JW. 1992. Wood properties of black locust (Robinia pseudoacacia L.): Physical, mechanical, quantitative chemical variability. Proc. Int. Conf., Michigan State University East Lansing, U.S.A.

STRINGER JW AND OLSON JR. 1987. Radial and vertical variations in stem properties of juvenile black locust (Robinia pseudoacacia L.). Wood Fiber Sci 19: 59-67.

TAPPI - TECHNICAL AsSOCIATION OF THE PULP AND PAPER INDUSTRY. 1988. Acid insoluble lignin in wood and pulp. Standard T 222 om 88.

YANG J, KAMdem DP, KeATHLEY DE AND HAN KH. 2004. Seasonal changes in gene expression at the sapwood-heartwood transition zone of black locust (Robinia pseudoacacia) revealed by cDNA microarray analysis. Tree Physiol 24: 461-474.

Zobel BJ ANd SpRague JR. 1998. Juvenile wood in forest trees. Springer Verlag. Berlin, Heidelberg, New York, $300 \mathrm{p}$.

ZoBel BJ AND VAN BUIJTENEN SP. 1989. Wood variation - its causes and control. Springer Verlag. Berlin, Heidelberg, New York, 363 p. 